(Uniwersytet Jagielloński, Kraków,

e-mail: beata.kiwit@uj.edu.pl)

ORCID: 0000-0002-0911-2047

\title{
WYMIENNOŚĆ PARTNERÓW ASPEKTOWYCH, CZYLI KILKA UWAG NA TEMAT IRRELEWANCJI ASPEKTU
}

\section{WPROWADZENIE}

Aspekt polskiego czasownika jest tematem, który doczekał się licznych językoznawczych opracowań, wielostronnych ujęć, a także reputacji niezwykle trudnego zagadnienia $z$ perspektywy glottodydaktycznej. Trudności cudzoziemców uczących się polskiego $z$ opanowaniem odnośnej kategorii, pytania zadawane przez nich w czasie wykładów i lektoratów, niejednokrotnie obnażające wątpliwości rodzimych użytkowników języka co do dokonaności / niedokonaności czasownika potwierdzają zasadność dalszych badań nad aspektem. Zwłaszcza, że te doczekały się wreszcie odpowiednich narzędzi, pochodzących $z$ obszaru semantyki kognitywnej, ${ }^{1}$ umożliwiających prowadzenie systematycznych porównawczych analiz materiałowych, które pozwalaja nie tylko na ustalenie zasad ekwiwalencji w zakresie wyrażania perfektywności / imperfektywności między językami aspektowymi i bezaspektowymi, ale także poszerzaja wiedzę na temat omawianej kategorii w samym języku polskim. Niniejszy artykuł opiera się właśnie na wynikach tego typu badan - analizy porównawczej wybranych rozdziałów dwóch współczesnych powieści: polskiej i niemieckiej oraz ich tłumaczeń. ${ }^{2}$ Badaniu poddane zostały wszystkie obecne w tekstach formy czasownikowe oraz ich obcojęzyczne ekwiwalenty w celu znalezienia odpowiedzi na pytania o repertuar funkcyjnych eksponentów dokonaności / niedokonaności w tekście niemieckim; o rzeczywisty procentowy udział w tym repertuarze wykładników

1 Za niezwykle istotne w tym kontekście uznać należy powstałe niezależnie, choć w dużej mierze zbieżne, koncepcje dwojga językoznawców - R. Grzegorczykowej [1997] oraz niemieckiego slawisty V. Lehmanna [1988; 1993; 2010].

2 Poddane analizie powieści to: Tartak Daniela Odiji [2003] oraz Adler und Engel Juli Zeh [2001]. Do badania wybrano po kilka ich rozdziałów wraz z tłumaczeniami - przeanalizowano około 80 stron każdej z powieści oraz odpowiadające tym fragmentom teksty przekładów. Wybraną literaturę cechuje świetna kompozycja, operowanie naturalnym, współczesnym językiem, duża świadomość językowa autorów. Obie powieści, bardzo pozytywnie odebrane przez krytyków, zostały przetłumaczone na wiele języków, co daje perspektywę prowadzenia dalszych badań porównawczych w zakresie wyrażania znaczeń aspektowych. 
kontekstowych powszechnie uważanych za najważniejsze; o znaczenie indykatora kognitywnego w wyrażaniu aspektu oraz o istnienie kontekstów umożliwiających w języku polskim wymienność partnerów aspektowych. Jako że trzy pierwsze $z$ wymienionych obszarów badawczych zostały już dość dokładnie omówione we wcześniejszych publikacjach [Terka 2018; 2020], niniejszy tekst koncentruje się na ostatnim z przywołanych zagadnień.

\section{KONTEKSTY UMOŻLIWIAJĄCE WYMIENNOŚĆ PARTNERÓW ASPEKTOWYCH ${ }^{3}$}

Analiza konkretnego współczesnego materiału pozwala na wskazanie szeregu użyć czasownika, w których aspekt uznać można za nierelewantny. Tym samym umożliwia weryfikację, uporządkowanie oraz uzupełnienie dotychczasowych - często intuicyjnych i jedynie ilustrowanych przykładami - obserwacji dotyczacych omawianego zagadnienia.

W pewnych kontekstach niemiecki czasownik w tekście nie musi aktywować określonego aspektu. Operacyjnym znakiem wspomnianej irrelewancji jest możliwość zastapienia w tekście polskim, bez spowodowania istotnej zmiany znaczenia, czasownika dokonanego - niedokonanym lub odwrotnie. Wbrew intuicyjnemu przekonaniu takie sytuacje stanowia znaczący odsetek. W tekście niemieckiego tłumaczenia polskiej powieści przypadki irrelewancji aspektu stanowia aż 12,7\% repertuaru ekwiwalentnych środków funkcyjnych odnośnej kategorii - repertuaru obejmującego także wykładniki kontekstowe, kognitywne, kognitywno-kontekstowe i gramatyczne [Terka 2018; 2020]. W tekście niemieckiego oryginału natomiast czasownik ambiaspektowy wystarcza w 4,4\% sytuacji. Przyczyn tak dużej dysproporcji upatrywać należy głównie w różnicach w narracji analizowanych powieści. W powieści niemieckiej bardzo często pojawiaja się formy czasu teraźniejszego, co $-z$ choćby czysto statystycznego punktu widzenia - ogranicza częstotliwość występowania kontekstów, których analiza pozwoliłaby uznać wyrażenie danej opozycji aspektowej za nieistotne. Przy obu kierunkach tłumaczenia można zaobserwować podobne grupy kontekstów wpływających na irrelewancję aspektu czasownika użytego w danym zdaniu czy szeregu zdań.

\subsection{Orzeczenia złożone $z$ czasownikiem modalnym}

Jedna ze wspomnianych wcześniej grup kontekstów stanowią orzeczenia złożone $z$ czasownikiem modalnym (przykłady (1)-(8) poniżej).

${ }^{3}$ Fragmenty niniejszego rozdziału oraz przytoczone w nim przykłady pochodza $z$ niepublikowanej rozprawy doktorskiej mojego autorstwa. 
tekst niemiecki $\rightarrow$ tekst polski: ${ }^{4}$

(1) Teraz Myśliwski śmiało mógt zatrudniać ludzi. $\rightarrow$ Nun konnte Myśliwski Leute einstellen.

(2) I znowu wszystko od nowa. Trzeba tylko wykonać nieco inne czynności, $w$ nieco innych okolicznościach. $\rightarrow$ Wieder geht alles von vorn los. Man muß nur etwas anderes tun, unter etwas anderen Bedingungen.

(3) Dwóch musiato ja przytrzymać, bo wyrywała się i wrzeszczała (...). $\rightarrow$ Zwei mußten sie festhalten, weil sie sich losreißen wollte, und sie schrie (...).

(4) (...) codziennie o świcie trzeba było wstawać, zapierdalać rowerem i dawać im żarło, wracać rowerem do roboty, a po robocie $z$ powrotem rowerem, by znowu dać tym ścierwom zmielona rybe $i$ tak przez dziesięc lat (...). $\rightarrow$ (...) jeden Tag mußte ich beim Morgengrauen aufstehen, mit dem Fahrrad hin, um ihnen was zum Fressen zu geben, dann mit dem Fahrrad wieder zurück zur Arbeit, und nach der Arbeit wieder mit dem Fahrrad hin, um diesen Biestern wieder Fischmehl zu geben, und das zehn Jahre lang (...).

(5) Aż trzeba było mrużyć oczy i przyktadać dłonie do czoła, by móc zobaczyć kto to. $\rightarrow$ Und sie mußten die Augen zukneifen und die Hand an die Stirn legen, um zu sehen, wer das war.

tekst niemiecki $\rightarrow$ tekst polski:

(6) Orangensaft, sagt sie. Ich habe welchen da und überlege, ob ich lügen soll. $\rightarrow$ Sok pomarańczowy - mówi. Tym razem jakiś mam, ale zastanawiam sie, czy nie powinienem sktamać.

(7) Ich habe es an der Tankstelle gekauft, einer plötzlichen Eingebung folgend-obwohl ich es nicht essen will. $\rightarrow$ Powodowany nagłym odruchem, kupilem je na stacji benzynowej - chociaż nie mam ochoty go zjeść.

(8) Erst will ich gar nicht hingehen (...). $\rightarrow$ Poczatkowo wcale nie zamierzam tam wchodzić (...).

Orzeczenia $z$ czasownikami modalnymi przede wszystkim informuja o konieczności, umiejętności, chęci czy możliwości robienia / zrobienia czegoś - czegoś, do czego odnosi się czasownik właściwy w danym zdaniu. Tym samym ów drugi, bezokolicznikowy człon orzeczenia pozbawiony zostaje bezpośredniego odwołania do konkretnej czynności, aktywności lub określonego zdarzenia, które wystapiły w przeszłości lub wystapić maja $\mathrm{w}$ przyszłości. Ich przedstawienie w przebiegu lub nie, jako powtarzajacych się bądź jednostkowych, nie jest zatem konieczne, a co najmniej nie

4 Strzałka oznacza kierunek tłumaczenia. 
wpływa w sposób istotny na znaczenie przekazu. W tym sensie zdania z czasownikami modalnymi przypominaja - by posłużyć się terminologia E. Koschmiedera [1934, 32-96] - „fakty bez wartości miejscowej” i sytuuja się po stronie pozaczasowości. Bliżej im do wypowiedzeń w trybie warunkowym czy rozkazującym niż do indykatywu, w którym zdecydowanie wyraźniej zaznaczaja się znaczeniowe różnice aspektowe - właśnie ze względu na jego referencję do „prawdziwej” akcji. ${ }^{5}$ Nie bez znaczenia jest tu też sama forma infinitywu, która otwiera pole do konkurencji aspektu zdecydowanie częściej niż verbum finitum. ${ }^{6} \mathrm{~W}$ poddanych analizie tekstach irrelewancję aspektu obserwuje się najczęściej w wypadku wykorzystania czasowników modalnych wyrażających konieczność czy powinność, zdecydowanie rzadziej przy tych wyrażających chęć lub możliwość. Przy okazji warto zaznaczyć (choć jest to temat na osobny artykuł), iż badany materiał nie potwierdza wyraźnej zależności między aspektem użytego bezokolicznika a typem modalności (deontycznej lub dynamicznej). Wybór jednego $z$ partnerów opozycji aspektowej w zdecydowanie większej mierze wydaje się podyktowany typem sytuacji - ogólnej (partner niedokonany) lub konkretnej (partner dokonany), do której dane zdanie się odnosi. ${ }^{7} \mathrm{Wy}-$ niki prowadzonych badań wskazuja jedynie na większą dowolność wyboru aspektu bezokolicznika w odniesieniu do modalności deontycznej niż dynamicznej. Problem ten wymaga jednak jeszcze dokładnej analizy oraz przeprowadzenia dalszych badań materiałowych.

\subsection{Konstrukcje bezokolicznikowe $z \mathrm{zu}$}

Druga grupę kontekstów, w których dość często możemy mówić o irrelewancji aspektu stanowia zdania zawierajace konstrukcje bezokolicznikowe z zu (przykłady (1)-(5)).

tekst polski $\rightarrow$ tekst niemiecki:

(1) (...) spytał zdecydowanie, na tyle jednak ostrożnie, by nie zaostrzać sytuacji. $\rightarrow$ (...) fragte er entschlossen, aber vorsichtig genug, um die Situation nicht zu verschärfen.

\footnotetext{
5 Na tę właściwość trybu oznajmującego wskazuje C. Piernikarski [1969, 92].

6 O związanej z pewnymi typami użyć bezokolicznika zmienności aspektu pisali już między innymi E. Koschmieder, C. Piernikarski i A. Holvoet. Ten ostatni zwracał też szczególna uwage na tendencję do neutralizacji opozycji aspektowych w wypadku predykatów niereferencjalnych, szczególnie zaś przy modalności deontycznej [Koschmieder 1934, 81-82; Piernikarski 1969, 92; Holvoet 1989, 162].

7 Do podobnego wniosku w odniesieniu do języka rosyjskiego dochodzi D. Divjak. Wyniki jej badań pokazuja jednak także pewne „preferencje” aspektu bezokoliczników wobec wyrażanych typów modalności [2009].
} 
(2) Ale Józef nie pozwalat żadnego oswoić. $\rightarrow$ Doch Józef gestattete es nicht, einen der Füchse handzahm zu machen.

tekst niemiecki $\rightarrow$ tekst polski:

(3) (...) gelang es mir, neue Tränen hervorzubringen. $\rightarrow$ (...) pomagała mi wydobywać $z$ siebie nowe Łzy.

(4) Ich hatte ohnehin nicht vor, jemals wieder die Augen zu öffnen. $\rightarrow$ (...) nie zamierzatem nigdy więcej otwierać oczu.

(5) Ich erfuhr etwas von einem Unglücksfall, aber ich überblicke zu wenig, um zu kondolieren. $\rightarrow$ Doszły mnie słuchy o jakimś nieszczęśliwym wypadku, ale zbyt słabo się orientuje, o co chodzi, żeby sktadać panu kondolencje.

Do przytoczonych przykładów po części odnoszą się wcześniejsze uwagi na temat orzeczeń $z$ czasownikami modalnymi. W przywołanych wyżej zdaniach formy bezokolicznikowe, których dotyczy zjawisko irrelewancji aspektu, nie oznaczaja akcji realnej, lecz jedynie potencjalna czy hipotetyczna. Konstrukcje $z$ zu w zdaniach współwystępują zresztą niejednokrotnie $z$ czasownikami modalnymi. W wielu wypowiedziach (np. w przykładach (1) i (5)) nie bez znaczenia jest też specyficzny charakter wykorzystanych fraz - zbliżajacy je bądź to do sformułowań metaforycznych, bądź to do powszechnie używanych wyrażeń idiomatycznych, co sytuuje je jeszcze wyraźniej po stronie ogólności. Poza tym warto zwrócić uwagę na występujące w polskich zdaniach w przykładach (2) i (3) niedokonane formy: pozwalat i pomagała. Wydaje się bowiem, że to ich imperfektywność otwiera pole do potencjalnej konkurencji aspektu w odpowiednich bezokolicznikach. W wypadku użycia dokonanych odpowiedników wymienionych czasowników perfektywna forma infinitywu byłaby bardziej naturalna.

\subsection{Mówić : powiedzieć}

W analizowanym materiale aspekt często uznaje się za nieistotny także w sytuacji, gdy użyte sa czasowniki mówić : powiedzieć (przykłady (1)-(4) poniżej). W tekstach niemieckiej powieści i niemieckiego tłumaczenia pojawia się w tym kontekście zawsze czasownik sagen.

tekst polski $\rightarrow$ tekst niemiecki:

(1) Ale ojciec mówit, że mały wyzdrowiał i ma sie dobrze. $\rightarrow$ Doch der Vater sagte, der Kleine sei gesund und wohlauf.

(2) Taka kobieta zyskiwała w oczach Marii dopiero, gdy w wywiadzie powiedziata coś o swoim dziecku albo mężu. $\rightarrow$ So eine Frau gewann in Marias Augen erst dann an Wert, wenn sie im Interview etwas über ihr Kind oder ihren Mann sagte. 
tekst niemiecki $\rightarrow$ tekst polski:

(3) Was hast du gerade gesagt, Baby? $\rightarrow$ Co powiedziataś przed chwila, baby?

O zmienności aspektu w zdaniach oznajmujacych $\mathrm{z}$ tymi czasownikami wspomina już E. Koschmieder [1934, 84]. Zaznacza on, iż w wypowiedziach typu: (ktoś) mówił / powiedziat, że różnica między względnościami kierunkowymi (z przeszłości w przyszłość lub odwrotnie) nie jest wystarczająco silna, aby tylko jeden $z$ aspektów był kategorycznie wymagany. M. Łaziński również zwraca uwagę na pewną dowolność (w określonych kontekstach) wyboru formy dokonanej lub niedokonanej [Łaziński 1997, 121]. Podkreślana tożsamość znaczenia dotyczy czasu przeszłego - tylko takie przykłady pojawiają się też w materiale stanowiącym podstawę badawcza niniejszego artykułu. W czasie przeszłym dla opisu jednostkowej sytuacji mówienia / powiedzenia czegoś można dość często pozwolić sobie na zamienne użycie partnera niedokonanego i dokonanego. Ma to zwiazek ze znaczeniem omawianych czasowników. Mówienie czegoś najczęściej oznacza powiedzenie czegoś, a powiedzenie czegoś implikuje prawdziwość tego wyrażenia także w wersji $z$ odpowiednikiem imperfektywnym. M. Łaziński za jeden $z$ przykładów owej tożsamości sensu uznaje znaczenie ogólnofaktyczne czasownika niedokonanego mówić, który użyty w odniesieniu do wydarzenia jednorazowego informuje tylko o tym, że czynność mówienia (i zdarzenie powiedzenia) czegoś w ogóle się odbyły. Konkretne okoliczności tej sytuacji czy dane dotyczące jej przebiegu zostają natomiast pominięte [Łaziński 1997, 122]. Badacz sugeruje jednak istnienie pewnych prawidłowości rządzacych wyborem jednego lub drugiego partnera $z$ omawianej pary aspektowej. Zaznacza, że czasownik imperfektywny - użyty we wspomnianym już znaczeniu jednokrotnym - wskazuje na bardziej nieokreśloną sytuację i dalsza przeszłość niż perfektywny wykorzystany w tym samym kontekście [Łaziński 1997, 137]. Przytoczone powyżej przykłady (1) i (3) mogłyby potwierdzać tę tezę, choć można przypuszczać, że mamy tu raczej do czynienia z pewna tendencja niż uniwersalną zasadą.

\subsection{Krotność ograniczona i powtarzalność uwarunkowana}

Następną grupę kontekstów otwierających pole do konkurencji aspektu stanowią zdania lub dłuższe fragmenty tekstu, które jednoznacznie wskazuja na wielokrotność lub powtarzalność czynności oznaczanej przez dany czasownik (przykłady (1)-(6) poniżej). 
tekst polski $\rightarrow$ tekst niemiecki:

(1) Nie spodziewał sie po nich zbyt wiele i brat wszystko, co podeszto mu pod krocze. $\rightarrow$ Er setzte keine großen Erwartungen in sie und nahm alles, was ihm unter die Lenden kam.

(2) Może dlatego jedyne, o czym śniła, to ich zakrwawione pyski, i już nie wiedziała, czy strach przed psami zarażał ja każdej nocy tym samym snem, czy to ten sen sprawit, że bała się psów. $\rightarrow$ Vielleicht war das der Grund, warum ihre blutigen Schnauzen das einzige waren, wovon sie träumte, und sie wußte schon nicht mehr, ob es die Angst vor den Hunden war, die sie jede Nacht mit demselben Traum ansteckte, oder ob dieser Traum bewirkte, daß sie vor den Hunden Angst hatte.

(3) Gdy odparzyła sobie stopy, zostawiała kalosze w domu i chodziła boso. $\rightarrow$ Wenn sie sich die Sohlen wund rieb, ließ sie die Galoschen zu Haus und ging barfuß.

(4) Wódka szybko rozwadniała krew i ta krew rozpędzała się $w$ żyłach. Pulsowała $w$ głowie $i$ bezwstydnie tłoczyła sie $w$ kroczu. Chłopaki pili tak, by nie stracić nic z tego, co wiło się na ekranie. Któryś coś bakknat, inny przytaknat, jakieś niedokończone słowo spadto pod ciężkie buty. $\rightarrow$ Der Wodka machte das Blut rasch dünner, so daß es durch die Adern jagte. Es pulsierte im Kopf und strömte schamlos in den Schoß. Die Burschen tranken so, daß sie nichts von dem, was sich auf dem Bildschirm abspielte, versäumten. Einer brummte etwas, ein anderer stimmte ihm zu, ein nicht zu Ende gesprochenes Wort fiel unter ihre schweren Stiefel.

tekst niemiecki $\rightarrow$ tekst polski:

(5) Ein paar Mal rief ich ihren Namen. $\rightarrow$ Kilka razy zawotatem ja po imieniu.

(6) Noch viermal werde ich ihn anschreien müssen, wahlweise mit Fäusten oder Stirn gegen die zugenagelten Türen trommeln, im Abstand von jeweils drei Minuten. $\rightarrow$ Jeszcze czterokrotnie bęę musiat wrzasnać, czterokrotnie walnąć piéściami lub czołem w zabite deskami drzwi, i tak co trzy minuty.

W przywołanych powyżej przykładach znaczenie wielokrotności / / powtarzalności - wynikające albo z użytego wykładnika leksykalnego (przykłady (2), (5)-(6)), albo z szerszego kontekstu (przykłady (1), (3)-(4)) - umożliwia w tekście polskim wymienność form aspektowych zaznaczonych czasowników. Irrelewancja aspektu ma tu ścisły zwiazek $z$ kontekstem krotności i wymaga jego dokładniejszej charakterystyki. Przytoczone konteksty można podzielić na takie, które wskazują, że coś działo się / / zdarzyło się kilka (lub określona liczbę) razy oraz na te, w których można 
byłoby użyć wyrażenia: ile razy..., tyle razy.... Możemy tu zatem mówić - za J. Stawnicka [2007] - o kontekstach krotności ograniczonej i powtarzalności uwarunkowanej. Badaczka, analizując użycie form aspektowych $z$ różnymi określnikami krotności w języku polskim i rosyjskim, także zauważa częste występowanie w przywołanych kontekstach konkurencji między perfektywnościa a imperfektywnościa w języku polskim, choć dodaje też, iż w narracyjnym typie tekstu ${ }^{8}$ ujawnia się tendencja do wyboru aspektu dokonanego [Stawnicka 2007, 54, 57]. Decyzja o użyciu we wszystkich zacytowanych wcześniej polskojęzycznych fragmentach czasowników dokonanych może wynikać właśnie $z$ ich zdolności dynamizowania narracji lub po prostu $z$ poczucia autora / tłumacza, iż niedokonaność formy werbalnej stanowiłaby tu swego rodzaju nadmiarowość i byłaby funkcjonalnie niepotrzebna, choć jak najbardziej możliwa.

\subsection{Inne konteksty}

Pozostałe wypadki irrelewancji aspektu nie pozwalaja jednoznacznie zaklasyfikować się do żadnej z wymienionych wcześniej grup, choć i dla nich można przynajmniej spróbować znaleźć uzasadnienie. Zaznaczyć przy tym należy, iż są to wypadki pojedyncze, występujące w badanym materiale sporadycznie (przykłady (1)-(5)).

tekst polski $\rightarrow$ tekst niemiecki:

(1) Alek opowiadat też, jak to byt raz na Manhattanie $w$ Nowym Jorku. $\rightarrow$ Alek erzählte auch, wie er einmal in Manhattan war.

(2) tym bardziej, że ten gwarantowat mu wielkie zamówienia, które miały dojść do skutku za jakieś pół roku. $\rightarrow$ Um so mehr, als ihm dieser große Bestellungen versprach, die in ungefähr einem halben Jahr einlangen würden.

(3) Cień, jaki rzucaty chmury, przyspieszył nadejście nocy. $\rightarrow$ Der Schatten, den die Wolken warfen, beschleunigte das Hereinbrechen der Nacht.

tekst niemiecki $\rightarrow$ tekst polski:

(4) Da muss doch Blut und Gehirn dran gewesen sein, hat das Radiomädchen während meines Anrufs gefragt. $\rightarrow$ Pewnie lepił się od krwi i rozpryśniętego mózgu, spytała dziewczyna $z$ radia, gdy do niej zadzwoniłem.

8 J. Stawnicka, badając funkcjonowanie form czasu przeszłego, nawiazuje do teorii podziału tekstów na dwa typy: narracyjny i deiktyczny [Stawnicka 2007, 54-57], o czym pisali między innymi J. Lyons [1989, 291], J. Forsyth [1970, 8-10, 64-66, 182 i nast.) i Ö. Dahl [1985, za: Stawnicka 2007, 54]. 
(5) Jetzt hat sie mich wohl darüber informiert, wie alt sie ist. $\rightarrow$ Teraz najwyraźniej poinformowata mnie o swoim wieku.

Przykłady (1), (4) i (5) wykazują bliski związek z wypowiedzeniami $\mathrm{w}$ czasie przeszłym zawierającymi czasowniki mówić: powiedzieć, więc dopuszczalna zmienność aspektu w omawianych zdaniach / fragmentach zdań tłumaczyć można podobnie jak w wypadku tamtych czasowników. W przykładzie (2) występuje brak ekwiwalencji leksykalnej między tekstem oryginału i tłumaczenia, aspekt jest jednak nierelewantny, co wynika ze znaczenia czasownika obiecać: obiecywać (lub: gwarantować: : zagwarantować), który w użyciu jednokrotnym, np. Obiecał, że przyjedzie / Obiecywat, że przyjedzie, pozwala się w uproszczeniu zdefiniować jako: Mówił / Powiedział, że (na pewno) przyjedzie. Niewątpliwie ważne jest też odniesienie „obietnicy” do sytuacji jedynie potencjalnej, przyszłej, a nie rzeczywiście zaistniałej. W zdaniu względnym w przykładzie (3) natomiast czasownik niemiecki werfen może $z$ powodzeniem odpowiadać polskiemu rzucać lub rzucić. E. Koschmieder wspomina o zmienności aspektu cechujacej niektóre zdania względne, pod warunkiem posiadania przez nie własnego punktu czasowego [Koschmieder 1934, 84]. W przywołanym przykładzie (w tekście wyjściowym) warto zwrócić uwage na czasownik w zdaniu nadrzędnym, który - gdyby był niedokonany sugerowałby raczej użycie imperfektywnego rzucać.

Badanie kontekstów, w których wybór między czasownikiem dokonanym a niedokonanym jest obojętny, prowadzi do jeszcze jednej interesującej obserwacji. Wydaje się, że istnieje pewien związek omawianego zjawiska irrelewancji $z$ typem dubletu aspektowego. W zdecydowanej większości sytuacji potencjalna wymienność czasowników perfektywnego i imperfektywnego dotyczy par tworzonych w wyniku sufiksacji (i alternacji), zdecydowanie rzadziej zaś pozostałych typów opozycji. ${ }^{9}$

Rozważając zagadnienie irrelewancji aspektu, warto wreszcie zatrzymać się na chwile przy jej związku $z$ formami trybu rozkazującego. $\mathrm{W}$ materiale analizowanym w ramach niniejszego artykułu pojawia się następujący przykład:

9 Możliwość istnienia takiej zależności sugeruje już E. Koschmieder [1934, 83-84]. Badacz bardziej wyraźna zmienność aspektu w wypadku przyrostkowych par aspektowych tłumaczy pełna tożsamością semantyczna obu ich członów (w przeciwieństwie do opozycji, w których partnera dokonanego tworzy się za pomoca przedrostka - zawsze, zdaniem badacza, w jakimś stopniu modyfikującego znaczenie czasownika). Choć autorka artykułu zdecydowanie nie zgadza się z teoriami ograniczającymi wykładniki opozycji aspektowej do sufiksów i przyjmuje aspektowość zarówno par przyrostkowych, jak i przedrostkowych, dostrzega jednocześnie $\mathrm{w}$ analizowanym materiale wspomniana interesujacca tendencję, która niewątpliwie wymaga dalszych badań. 
Hör zu, sagt Maria Huygstetten, ich weiß, dass wir nichts mehr miteinander zu tun haben werden. $\rightarrow-$ Posłuchaj - mówi Maria Huygstetten - wiem, że już nic nie będzie nas łaczyło.

Takie użycie niemieckiego czasownika zuhören nie musi wskazywać na polski aspekt dokonany, w tłumaczeniu $z$ powodzeniem mogłaby się pojawić forma słuchaj. W większości innych przypadków użycia trybu rozkazującego (w jego formach niezaprzeczonych) trudno jednak mówić o dowolności aspektowej. Wraz ze zmiana formy perfektywnej na imperfektywna dochodzi bowiem do zmiany tonu wypowiedzi na bardziej zdecydowany, wyrażający przy tym zniecierpliwienie. ${ }^{10}$ Zmienność aspektu $\mathrm{w}$ przywołanym powyżej przykładzie może mieć związek z przynależnościa czasownika słuchać do klasy czasowników aktywnościowych. Nie tworzy on właściwej opozycji aspektowej. Wspomniane różnice w wyrazie emocjonalnym między użyciem perfektywów i imperfektywów w trybie rozkazującym zaznaczaja się zdecydowanie wyraźniej w wypadku prototypowych par aspektowych.

\section{PODSUMOWANIE}

Porównawcze badania materiałowe pozwalaja dostrzec rzeczywisty zakres zjawiska irrelewancji aspektu. Konteksty, w których odnośna kategoria gramatyczna jako obligatoryjna w języku polskim ma $\mathrm{w}$ istocie charakter redundantny, nie sa tak rzadkie, jak można byłoby przewidywać. Ponadto pozwalają się one dość precyzyjnie wyodrębnić i opisać. Ich weryfikacji, uszczegółowieniu oraz potencjalnemu poszerzeniu służyć powinny dalsze badania empiryczne nad aspektem. Zaprezentowane $\mathrm{w}$ niniejszym artykule wyniki analizy materiałowej oraz wnioski $z$ niej płynące moga znaleźć zastosowanie w glottodydaktyce polonistycznej. Obcokrajowcy na wyższych poziomach zaawansowania językowego zaczynaja używać form dokonanych i niedokonanych coraz bardziej intuicyjnie. Wpływa na to osłuchanie się z przyswajanym językiem. To samo osłuchanie rodzi jednak nowe watpliwości, niejednokrotnie burzace starannie budowany przez lata porządek w zakresie regul i kontekstów użycia poszczególnych partnerów aspektowych. Wątpliwości te często dotyczą właśnie irrelewancji aspektu. Trudne zagadnienie wymienności aspektowej powinno zatem znaleźć należne sobie miejsce nie tylko w tekstach naukowych poświęconych tej kategorii, ale także w podręcznikach oraz innych materiałach dydaktycznych do nauczania języka polskiego jako obcego.

10 W. Śmiech [1971, 130] owo wrażenie większego nacisku wyrażanego przez czasownik niedokonany wywodzi $z$ bardziej aktualnego znaczenia form imperfektywnych. 


\section{Bibliografia}

D. Divjak, 2009, Mapping between domains. The aspect-modality interaction in Russian, „Russian Linguistics” 33, s. 246-269.

J. Forsyth, 1970, A Grammar of Aspect. Usage and Meaning in the Russian Verbs, Cambridge.

R. Grzegorczykowa, 1997, Nowe spojrzenie na kategorię aspektu w perspektywie semantyki kognitywnej [w:] R. Grzegorczykowa, Z. Zaron (red.), Semantyczna struktura słownictwa $i$ wypowiedzi, Warszawa, s. 25-38.

A. Holvoet, 1989, Aspekt a modalność w języku polskim na tle ogólnosłowiańskim, Wrocław.

E. Koschmieder, 1934, Nauka o aspektach czasownika polskiego $w$ zarysie. Próba syntezy, Wilno.

V. Lehmann, 1988, Der russische Aspekt und die lexikalische Bedeutung des Verbs, „Zeitschrift für slavische Philologie” 48, s. 170-181.

V. Lehmann, 1993, Die russischen Aspekte als Gestufte Kategorien (Ein Beispiel für die Bedeutung der kognitiven Linguistik in der slavistischen Sprachwissenschaft), „Die Welt der Slaven” 38/2, s. 265-297.

V. Lehmann, 2010, Der slavische Aspekt im Licht der kognitiven Linguistik [w:] T. Anstatt, B. Norman (red.), Die slavischen Sprachen im Licht der kognitiven Linguistik, Wiesbaden, s. 77-99.

J. Lyons, 1989, Semantyka 2, tłum. A. Weinsberg, Warszawa.

M. Łaziński, 1997, Opozycja czasowników mówić-powiedzieć w języku polskim. Analiza leksykalna i aspektowa [w:] R. Grzegorczykowa, Z. Zaron (red.), Semantyczna struktura słownictwa $i$ wypowiedzi, Warszawa, s. 121-147.

D. Odija, 2006, Das Sägewerk, tłum. M. Pollack, Wien.

D. Odija, 2003, Tartak, Wołowiec.

C. Piernikarski, 1969, Typy opozycji aspektowych czasownika polskiego na tle słowiańskim, Wrocław-Warszawa-Kraków.

J. Stawnicka, 2007, Aspekt - iteratywność - określniki kwantyfikacyjne: na materiale form czasu przeszłego w języku polskim, Katowice.

W. Śmiech, 1971, Funkcje aspektów czasownikowych we współczesnym języku ogólnopolskim, Łódź.

B. Terka, 2018, Aspekt polskiego czasownika jako problem przekładu oraz wyzwanie dla uczacych się i nauczajacych języka polskiego jako obcego [w:] B. Grochala, I. Dembowska-Wosik (red.), „Acta Universitatis Lodziensis. Kształcenie Polonistyczne Cudzoziemców” 25, Łódź.

B. Terka, 2020, Słowiański aspekt polskiego czasownika w ujęciu kontrastywnym a glottodydaktyka polonistyczna [w:] M. Biernacka, I. Janowska (red.), Kierunki badań w glottodydaktyce polonistycznej, w druku.

J. Zeh, 2001, Adler und Engel. Roman, Frankfurt am Main.

J. Zeh, 2004, Orły i anioły, tłum. S. Lisiecka, Warszawa. 


\section{Alternation of aspectual partners, or a few comments on the irrelevance of aspect}

\section{Summary}

This paper discusses the issue of irrelevance of the aspect of the Polish verb. In specific contexts, the grammatical category of aspect, being obligatory in the Polish language, is in fact redundant. The identification of such contexts (and hence review of the most important current observations and convictions in this respect), the attempt at ordering and describing them enabled systematic material research based on a (Polish-German and German-Polish) translation. The findings presented in the paper might be a good starting point for a reflection on the reasonability of including the described issue in curricula of teaching Polish as a foreign language. Due to its reach and frequency, the phenomenon of alternation of aspectual partners should be more frequently discussed in the literature dedicated to aspect and Polish glottodidactics.

Keywords: aspect - aspectual pair - irrelevance - empirical research - translation - language teaching - Polish language - German language - glottodidactics.

Trans. Monika Czarnecka 